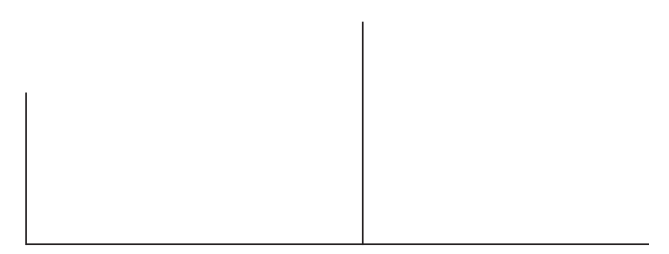

Rev. Latinoam. Psicop. Fund., II, 3, 166-172

\title{
A grande histeria ou hístero-epilepsia ${ }^{1,2}$
}

\author{
Jean-Martin Charcot
}

(Uma doente trazida numa maca entra na sala de aulas).

Sr. Charcot: Esta é uma doente que vocês já viram sextafeira passada. Posteriormente a uma queda, ela foi acometida de uma contração do membro inferior direito dando origem a uma deformação no pé que a faz mancar.

Nada é mais freqüente numa histérica do que vermos uma contração produzir-se após um traumatismo: trata-se de saber o que se pode fazer em casos como esse. Eu lhes havia dito que seria necessário eliminar a contração histérica assim que a víssemos aparecer.

Mas aqui estamos um pouco fora da regra; nós esperamos três ou quatro dias e eu lhes disse as razões pelas quais cometemos essa infração; é que nos doentes do tipo dessa mulher, geralmente é bastante possível provocar um ataque que em certas circunstâncias é uma espécie de recurso terapêutico. Acontece freqüentemente de um ataque provocado dessa maneira resultar numa mudança visível e que uma contração

1. Leçons du mardi, 1887-1888, pp. 173-179.

2. Tradução de e revisão técnica do Prof. Dr. Mário Eduardo Costa Pereira (Laboratório de Psicopatologia Fundamental-UNICAMP) 


\section{CLÁSSICOS DA}

PSICOPATOLOGIA

que parecia ser irredutível e que duraria indefinidamente desapareça por tal influência. Vocês me dirão: será que não há alguma coisa de imoral em práticas dessa natureza? Seguramente não, se pudermos através desse meio fazer desaparecer um mal local, contra o qual de outra forma seríamos impotentes.

E eu lhes mostrei que há uma correspondência entre os fenômenos de histeria local que duram como esse há 5 ou 6 meses e as crises nervosas: muitas vezes não é nas pessoas que têm ataques que aparecem as contrações: ao contrário, nelas as contrações não existem.

Em virtude dessa doutrina que foi destacada com muita razão pelo Sr. Pito é que acreditamos ser preciso saber aproveitar a existência dos pontos histerogênicos para provocar um ataque em determinado momento.

Pois bem! Esta doente irá nos servir para demonstrar o que estou adiantando. Entretanto eu lhes direi que, mesmo que estejamos quase certos do resultado anunciado, as coisas do organismo não são tão precisas como as coisas da mecânica, e eu não me espantaria se nossa operação falhasse. Algumas vezes dizemos que as experiências com animais, quando são feitas em público, não são tão bem-sucedidas como as que são feitas em laboratório; o que é verdadeiro para esses casos é também com mais razão para as experiências clínicas que fazemos aqui. E mesmo que não tenhamos o êxito que desejamos, não deixará de haver aí uma lição para vocês.

Esta doente tem um ponto histerógeno nas costas, um outro sob o seio esquerdo e ainda outro no membro inferior. É isso que utilizaremos de forma a conseguirmos todas as vantagens possíveis .

Se o ataque se produzir como acredito, eu os convido a acompanharem por vocês mesmos todas as suas fases, o que não é fácil, pois precisei de longos anos para consegui-lo.

Recebi muito desse serviço, cujo chefe, que o dirigia muito bem há cerca de quinze ou vinte anos, era o Sr. Delasiauve, e desde os primeiros momentos fui testemunha desses ataques hístero-epiléticos. Eu me conduzia com a maior circunspecção em meus diagnósticos, pois me questionava sobre como seria possível que essas coisas não estivessem nos livros? De que maneira agir se quiséssemos descrever o ataque tal como ele se apresenta naturalmente? Eu apenas via uma absoluta confusão e a impotência à qual estava reduzido me causava uma certa irritação; até que um dia, por uma espécie de intuição, eu pensei: mas é sempre a mesma coisa; concluí então que havia aí uma doença específica, a histeria major (superior), começando por um ataque epileptóide que difere tão pouco do verdadeiro ataque de epilepsia que foi denominada doença hístero-epilética, apesar de ela não ter nada em comum com a epilepsia.

A fase epileptóide se subdivide em período tônico seguido do período clônico; vem em seguida o silêncio e a fase dos grandes movimentos, a qual apresenta dois aspectos principais: as saudações e o arco de círculo. Nessa fase, ora é o arco de 


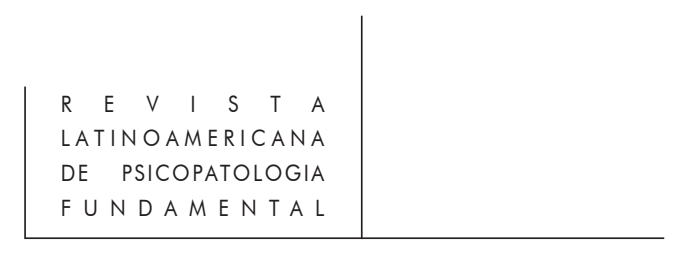

círculo que domina, ora as saudações. Chega-se finalmente a uma terceira fase. Bruscamente vocês vêem a doente olhando uma imagem fictícia; é uma alucinação que varia segundo as circunstâncias: ora a doente dá sinais de espanto, ora sinais de alegria, se o espetáculo que ela acredita ter diante dos olhos for assustador ou agradável. Vocês já conhecem tudo isso e a mulher adormecida que vocês viram outro dia pode lhes dar uma idéia disso. Quando eu a toquei na região ovariana, vocês a viram sair de sua cama, se precipitar para esse canto e pronunciar palavras que indicavam o maior assombro. Mas o que é preciso ver é o desenrolar dos fenômenos do ataque. Eu os previno para que vocês possam observar o que tem para ser visto, e é, repito, muito difícil de ver bem essas coisas. O que quero lhes mostrar é que não há uma sucessão de ataques que acontecem, mas um ataque que se desenvolve. Vocês verão que eu emprego aqui o método dos tipos. O tipo contém o que há de mais completo na espécie. Depois, assim como isso acontece em todas as doenças nervosas, é preciso aprender a cindir seu tipo. O período epileptóide pode não ocorrer, o ataque começa imediatamente pelos grandes movimentos, as saudações, o arco de círculo. Às vezes são os grandes movimentos que faltam, e a coisa começa pelas alucinações: o ataque vem em seguida. Há umas vinte variedades, mas se, partindo da base, vocês retornarem imediatamente ao tipo que reconstituiram internamente, ao fim de um certo tempo, dirão a vocês mesmos: apesar da imensa variedade aparente dos fenômenos, é sempre a mesma coisa.

Pois bem! Eis aí o pé caído. Eu não ousaria dizer nesse caso que ele não tenha se movimentado nem durante o dia, nem durante a noite, mas é muito provável. Não é um pé caído que possa se resolver durante a noite, é um pé caído fixo, não é simulação. Vocês sabem que a mania de simulação é um dos principais obstáculos na neuropatologia.

(O médico residente toca o ponto histerógeno situado sob o seio esquerdo. Imediatamente começa o ataque).

Sr. Charcot: Eis aí o período epileptóide.

Período epileptóide, arco de círculo, saudações; como vêem, o arco de círculo é bastante pronunciado. Agora, eis o período das atitudes passionais que se confunde até certo ponto com o período do arco de círculo, depois em seguida um ataque de contração que às vezes ocorre em circunstâncias semelhantes, de tal maneira que se isso permanecesse assim nós não teríamos avançado muito mais.

O período epileptóide recomeça agora com suas duas fases; a primeira fase é a dos movimentos tônicos e, a segunda, a dos movimentos clônicos. Vocês vêem como isso é semelhante à epilepsia.

Nós vamos ver se a doente é ovariana.

(Exerce-se uma pressão sobre a região ovariana).

Façam isso numa epilética, não acontecerá nenhuma modificação, e isso lhes mostra de imediato a diferença que existe entre a hístero-epilepsia e a epilepsia. A 


\section{CLÁSSICOS DA \\ PSICOPATOLOGIA}

epilepsia não está de forma alguma sob a dependência ovariana, enquanto aqui é totalmente diferente. Vocês vêem que o ataque é interrompido sob a influência da pressão.

É verdade, sim ou não, que a compressão do ovário produz a parada do ataque? Vocês verão nos livros, que parecem terem sido feitos com conhecimento de causa, que isso não acontece. Isso não se vê na Inglaterra, diz alguém; isso, diz um outro, também não se vê na Alemanha. Os que fazem essa afirmação são pessoas que se precipitam em fazer generalizações. Mas a partir do momento em que o fato existe em Paris, é muito possível acreditar que aconteça também em outros lugares. Vamos interromper a compressão do ovário e vocês irão observar o ataque voltar como ainda agora. Eis o período epileptóide que começa. Freqüentemente no estrangeiro chama-se isso de epilepsia. Evidentemente os que fazem isso não podem entenderse conosco; nós mesmos dizemos hístero-epilepsia ou histeria major. Eis aí agora o arco de círculo: vocês verão que mecanismo, que regularidade; é sempre a mesma coisa.

Sua contração persiste. Se assim não tivermos êxito para liberá-la, adotaremos outra conduta depois do ataque, e teremos mais chance de sucesso que se a tivéssemos abordado de chofre sem ter provocado essa espécie de crise nervosa salutar que poderá se prolongar ainda durante longo tempo, pois o caráter dos ataques hísteroepiléticos é de formar séries infindáveis: pode durar todo o dia. Os doentes saem apenas cansados, característica que mostra bem que a hístero-epilepsia não tem nada a ver com a epilepsia. Quando os ataques de epilepsia se unem uns aos outros de maneira a formar séries cujos términos são tão próximos que eles se sobrepõem, vocês tem o que chamamos de estado de mal. Ora, o estado de mal epilético é um estado de mal dos mais graves, que freqüentemente chega a um término fatal. Na hístero-epilepsia, ao contrário, os ataques se sucedem sem intervalos durante um dia, dois dias, três dias, sem perigo para o doente. O estado de mal hístero-epilético não tem, portanto, o caráter grave do estado de mal epilético.

Acabamos de pressionar novamente um ponto histerógeno e eis que o ataque epilético se reproduz. Algumas vezes, não com freqüência, a doente morde a língua. Agora, eis aqui o famoso arco de círculo, cuja descrição vocês encontram em qualquer lugar.

(Subitamente a doente grita: Mamãe, eu tenho medo!).

Eis as atitudes passionais; depois se deixássemos as coisas caminharem, reencontraríamos o ataque epiléptiforme.

Um tipo de resolução é produzida e seguida de uma espécie de contração. Isso ocorre algumas vezes como fenômeno acessório aos ataques.

(A doente grita: Ah, mamãe!).

Vocês vêem como as histéricas gritam. Pode-se dizer que é muito barulho por nada. A epilepsia, que é mais grave, é muito mais silenciosa. 
R $\quad E \quad V \quad$ I $S$ S $T$ T

LATINOAMERICANA

DE PSICOPATOLOGIA

F UNDAMENTA L

Eu não sei qual será o resultado dessa tentativa, mas não estou aborrecido por haver mostrado um ataque mais ou menos comum, a saber: uma fase epileptóide composta de duas partes, tônica e clônica, depois uma fase de grandes movimentos,... e logo em seguida a fase das atitudes passionais que são aqui de um só tipo, o tipo triste, fases seguidas de uma espécie de contração.

Há pouco essa doente estava rígida; em geral há pouca rigidez, as atitudes são inteiramente reais, posturas plásticas.

Há ainda uma quarta fase, mais rara, e que não está presente em nossa doente: é o período de delírio.

Aqui, depois da fase das atitudes passionais, o mesmo processo recomeça, vocês podem observar séries que se sucedem e o ataque pode durar assim indefinidamente, dois dias, três dias, seis dias. A compressão do ovário só pode produzir o efeito que vocês viram nas doentes ovarianas. Mas nem todas são ovarianas. Volto sempre a essa lenda que criaram a meu respeito e sobre a qual já me expliquei. Eu seria a causa das operações que são feitas na América, ablações do ovário que são praticadas em decorrência de hístero-epilepsia. Estou completamente fora de tudo isso. Eu disse a verdade; é que existem doentes que têm um ponto ovariano doloroso e que quando esse ponto doloroso existe, pode-se aproveitá-lo, não para fazer cessar (ou desaparecer) completamente o ataque, mas para suspendê-lo. E suspender o ataque não é absolutamente curá-lo, é conseguir um pouco de tranqüilidade. Vamos colocar um aparelho de compressão nessa doente e momentaneamente ela não terá mais ataques, mas um belo dia será necessário tirar-lhe o cinto porque ela não pode conservá-lo indefinidamente e então, provavelmente, o ataque se reproduzirá. A compressão do ovário é apenas um meio preventivo, e também um meio de ter paz: não é absolutamente um meio de cura. E se vocês retirarem o ovário, isso não resulta no favorecimento da cura da histeria. Por outro lado, não se deve pensar que exista apenas o ovário cuja compressão traz o apaziguamento momentâneo dos ataques. Algumas vezes os pontos histerógenos têm a mesma propriedade; isso depende do caso. Existem pontos espasmogênicos e pontos inibidores. Assim, essa doente tem uma placa histerógena sob o seio. Eu poderia ter comprimido essa parte mais fortemente do que quando se quer provocar a crise e o ataque teria parado.

Ninguém jamais teria a idéia de retirar um fragmento histerógeno para curar uma hístero-epilética. Portanto, eu jamais disse o que atribuíram a mim. Não sou absolutamente favorável às práticas americanas e lavo minhas mãos a esse respeito. Eu soube que haviam mulheres histéricas que eram ovarianas e homens histéricos que eram testiculares, mas nem todos os histéricos homens são testiculares e nem todas as histéricas são ovarianas. Eis a verdade. Eu nunca disse outra coisa; não tenho o hábito de sustentar coisas que não sejam experimentalmente demonstráveis. Vocês sabem que tenho por princípio não levar em conta a teoria e deixar de lado 


\section{CLÁSSICOS DA \\ PSICOPATOLOGIA}

todos os preconceitos; se vocês quiserem ver claro, é preciso tomar as coisas como elas são.

Parece que a hístero-epilepsia existe apenas na França e eu poderia mesmo dizer, e já foi dito algumas vezes, existe apenas na Salpêtrière, como se eu a tivesse forjado pela potência de minha vontade. Seria realmente uma coisa maravilhosa que eu pudesse assim criar doenças ao sabor de meu capricho e de minha fantasia. Mas a bem da verdade, eu estou aí apenas como o fotógrafo; eu inscrevo o que vejo e é muito fácil para mim mostrar que não é apenas na Salpêtrière que essas coisas acontecem. Primeiramente as encontramos em grande quantidade nos relatos dos endemoniados da Idade Média. O Sr. Richer mostra-nos em seu livro que no século XV era exatamente como hoje.

Recebemos numerosas correspondências, vindas principalmente da América do Norte, que no entanto não tem relações com a Salpêtrière - correspondências provocadas pela descrição que eu fiz do ataque hístero-epilético, e onde nos mostram hístero-epiléticos comportando-se exatamente como os nossos.

Na Inglaterra há um médico eminente, Sr. Gowers, que não acredita em minhas descrições. Vejamos então como ele arranja as coisas. Num tratado sobre epilepsia, ele usa essas expressões: “Acidentes histéricos pós-epiléticos”; ele toma a primeira fase epileptóide, que vocês viram ocorrer em conseqüência da pressão ovariana, por um acesso de epilepsia, e então descreve todos os fenômenos aos quais vocês assistiram, e chama isso de acidentes pós-epiléticos. Por que? Porque numa doente existem acidentes epileptiformes do começo que a perturbam. Ela apenas vê esses acidentes com nomes diversos. Eu mantenho a unidade da coisa, a fixidez da espécie. Eis aí o ataque hístero-epilético e eu não saio daí.

Vocês sabem (não fui eu que inventei isso, mas os que me precederam no serviço que dirijo) distinguir os ataques de crises mistas dos ataques de crises independentes. O que isso quer dizer?

Eis uma doente: periodicamente ela tem crises. Eu digo: ela é histérica, mas ela é comicial, para complicar a situação. Vocês compreendem o que isso significa, é que ela tem duas doenças essencialmente diferentes, ainda que pertencentes à mesma família, como a gota e o reumatismo. Pois bem! As espécies mórbidas têm uma fixidez relativa e falando praticamente, a doutrina da fixidez das espécies mórbidas deve ser considerada como verdadeira. Com efeito, as espécies mórbidas, felizmente, não variam tanto quanto se poderia acreditar. Não se deve fazer darwinismo sem razão. Na doutrina da evolução, o principal fator é o tempo e somente consideramos a fixidez das espécies mórbidas do ponto de vista da época em que vivemos.

Eu afirmo que no caso do mal com crises independentes há, de início, um ataque de histeria maior depois uma crise de epilepsia diversa. Freqüentemente, após um ataque de histeria, as doentes mordem a língua, endireitam-se na cama e a pessoa em serviço que vê uma doente nessa situação diz que ela teve um acesso. Quando 


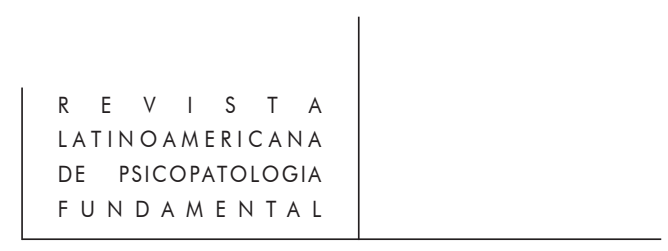

isso não ocorre, ela diz: ela teve um ataque. Há, efetivamente, uma diferença entre essas duas fórmulas: alguém tem um ataque, ou então alguém tem um acesso. Quando se disser que ela tem um acesso, será grave. Mas se essa pessoa tem ataques, isso pode acontecer durante três ou quatro dias, cinco dias, seis dias sem causar perigo. Alguém tem acessos: segue-se algumas vezes o que se chama de estado de mal; procura-se o médico, a temperatura se eleva, a vida está em perigo. Vocês vêem o quanto a diferença é grande e capital. Num caso vocês têm pontos histerógenos, vocês podem recorrer, mesmo que seja apenas com um objetivo experimental, e em todo caso, parar o ataque, enquanto se vocês tiverem que lidar com acessos, a compressão de pontos histerógenos não servem absolutamente para nada.

Acrescentarei ainda que, enquanto o brometo de potássio tem pelo menos uma ação paliativa nos acessos de epilepsia, no caso dos ataques, ao contrário, ele é absolutamente inútil; vocês podem ministrá-lo às toneladas sem nada mudar no estado das doentes. A grande histeria não é epilepsia. A união entre essas duas doenças se dá na hereditariedade. Um hístero-epilético pode engendrar um epilético, um epilético um hístero-epilético, mas é preciso dizer também que tanto um quanto outro podem engendrar maníacos, vesaníacos; eu já lhes disse que a árvore neuropatológica tem numerosos galhos, e cada um desses galhos pode dar frutas diversas. 